\title{
Influence of Sampling Sites on the Occurrence and Distribution of Cellulose Degrading Microbial Communities
}

\author{
Gurpreet Singh, Neemisha*and Sandeep Sharma
}

Department of Soil Science, Punjab Agricultural University, Ludhiana, Punjab 141004, India

*Corresponding author

\begin{tabular}{|c|}
\hline Keywords \\
\hline $\begin{array}{l}\text { Sampling sites, } \\
\text { Cellulose, } \\
\text { Microbial } \\
\text { communities }\end{array}$ \\
\hline Article Info \\
\hline $\begin{array}{l}\text { Accepted: } \\
\text { 12 July } 2018 \\
\text { Available Online } \\
10 \text { August } 2018\end{array}$ \\
\hline
\end{tabular}

\section{Introduction}

The microbes are considered as pillars of life on earth as they play a major role in the nutrient cycling. Plant residues are generated in huge quantities throughout the world. Under natural conditions the degradation of plant residues is carried out by specific group of microorganisms which are involved in C- cycle. Addition of compost or wood residuals to topsoil results in an increase in carbon availability for beneficial soil microorganisms as well as maintains physical, chemical and biological properties of soil (Munten, 2005; Larney and Angers, 2012). Forest ecosystem represents a niche with enriched biodiversity of both microbes and plants which grows on relatively nutrient-poor soils. In order to fulfill 
the nutrient requirements, the microorganisms present in these systems have developed enzymatic systems for the rapid turnover of organic matter and hence these processes results in rich plant diversity in the forest (Parton et al., 2007). Plant residues consist of variable fractions of cellulose, lignin and hemicelluloses. Cellulolytic microorganisms are an important part of carbon cycle and they produce enzymes, which are responsible for the hydrolysis of cellulose. Enzymatic hydrolysis involves a series of enzymes, which act in a synergistic way to completely hydrolyze cellulose to simple sugars ( $\mathrm{Yu}$, 2007). The product of one enzyme acts as a substrate for another enzyme and in this way cellulase system completely degrades cellulose to simple sugars. The goal was to isolate cellulolytic microorganisms from diverse climatic conditions. Exploring the cellulolytic enzymatic potential in the residue degradation may lead to the production of improved end product that could be useful in enhancing the ex-situ composting

\section{Materials and Methods}

\section{Site of sampling}

The samples were collected to assess the performance of different agricultural systems from different sites of Punjab, Haryana and Himachal Pradesh using wide range of indicators (crop residues, composting sites, forest, crop establishment, crop rotation, rotten wooden $\operatorname{logs}$, termite mounds in forest, cow dung piles).

\section{Sampling procedure and preservation}

The sampling sites were selected from hot spots of cellulolytic getting maximum population of cellulolytic microorganisms. Samples were collected randomly from different spots using auger. The collected samples were packed in polythene bags and either processed on the same day or kept in deep freezer at $-20^{\circ} \mathrm{C}$ till further use.

\section{Isolation and maintenance of cultures}

The isolation of microbes was done using two methods. In first method 10 grams of the respective samples was transferred to Erlenmeyer flask $(150 \mathrm{ml})$ with $90 \mathrm{ml}$ sterilized water and 5\% CMC followed by shaking at $120 \mathrm{rpm}$ for 7 days to encourage the growth of cellulolytic microbes whereas, in the other method direct serial dilution of the samples was prepared. In both the methods, Nutrient agar, rose Bengal agar and Kenknight's medium was used for selective isolation of bacteria, fungi and actinomycetes and the media was autoclaved at $15 \mathrm{psi}$ and $121^{\circ} \mathrm{C}$ for 20 minutes. Serial dilution of the sample was made up to $10^{-6}$ dilution and appropriate dilutions $(100 \mu \mathrm{l})$ were pour plated or spread plated using Rose Bengal medium (Papaic digest of soybean meal: 5.0, Dextrose: 10.0, Monopotassium phosphate: 1.0, Magnesium sulphate: 0.5, Rose Bengal: 0.05, Agar: 15.0 and Final pH 7.2 \pm 0.2 ) for isolation of fungi, nutrient agar medium (Animal tissue peptic digest: 5.0, Sodium chloride: 5.0, Beef extract: 1.5 , Yeast extract: 1.5 , Agar: $15.0, \mathrm{pH}$ $7.4 \pm 0.2)$ for isolation of bacteria and Kenknight's medium (Dextrose: 1.0, monopotassium dihydrogen phosphate: 0.1 , sodium nitrate: 0.1 , potassium chloride: 0.1 , Magnesium sulphate: 0.1 and agar: 15.0) for actinomycetes then were incubated at $30^{\circ} \mathrm{C}$ for 4-7 days for the isolation of microbial colonies. Morphologically different colonies were selected for isolation and sub-culturing. Microbial colonies were picked carefully and every single colony was maintained on slants.

\section{In vitro screening of cellulolytic activity}

\section{Qualitative assay for cellulase}

The presence of cellulose degrading capability was tested by using cellulolytic basal medium 
(Minamiyama et al., 2003), with the following ingredients: CMC agar medium I was used for the isolation of bacteria and actinomycetes. The media consisted of $(\mathrm{g} / \mathrm{L}) \mathrm{NaNo}_{3}: 2.0$, $\mathrm{K}_{2} \mathrm{HPO}_{4}$ : $1.0, \mathrm{MgSO}_{4}: 0.5, \mathrm{KCL}: 0.5, \mathrm{CMC}$ Na Salt: 2.0, Peptone: 0.2 and Agar: 20.0. Cellulolytic basal medium II was used for isolation of fungi. The components of medium are as $(\mathrm{g} / \mathrm{L}): \mathrm{KH}_{2} \mathrm{PO}_{4}: \quad 0.5$ Ammonium tartarate: $0.5 \mathrm{MgSO}_{4}: 0.1, \mathrm{CaCl}_{2} .2 \mathrm{H}_{2} \mathrm{O}: 0.01$, Yeast extract: $0.001, \mathrm{CuSO}_{4}: 0.001, \mathrm{Fe}\left(\mathrm{SO}_{4}\right)_{3}$ : 0.001, $\mathrm{MnSO}_{4}: 0.001 \mathrm{CMC}: 20.0$ and Agar: 20.0. The various components were dispensed in $1000 \mathrm{ml}$ sterilized water and media was autoclaved at $121^{\circ} \mathrm{C}$ at a pressure of $15 \mathrm{lbs}$ psi for 20 minutes.

\section{Screening of cultures for cellulolytic potential}

The plates were inoculated by spotting for bacteria and actinomycetes on CMC media (I) and $6 \mathrm{~mm}$ agar discs cut from 5 day old fungal culture on CMC media (II) of each strain separately and were incubated at $30^{\circ} \mathrm{C}$ in darkness. After 4-7 days the plates were flooded with Congo red dye $(2 \% \mathrm{w} / \mathrm{v})$ for 15 min. Then, the petriplates containing medium were rinsed with distilled water followed by flooding with $1 \mathrm{M}$ sodium chloride for $1 \mathrm{~min}$. Yellow opaque area around the colonies represented cellulase activity of microorganisms. The diameter of bacterial, fungal or actinomycetes colony and zone diameter were recorded to determine zone of hydrolysis obtained.

\section{Results and Discussion}

A total of 27 samples representing forest ecosystem, composting units, rotten wooden $\operatorname{logs}$, termite mounds in forest, incorporation experiments, cow dung piles etc. were collected from different locations (Table 1). All the samples were processed using serial dilution plating on different media such as Nutrient agar, Kenknight medium and Rose
Bengal medium for isolation of bacteria, actinomycetes and fungi, respectively (Figure 1). Based on different morphotypes obtained on respective media, the colonies of bacteria, actinomycetes and fungi were isolated. A total of 520 bacterial cultures, 33 actinomycetes and 100 fungi were isolated. All the cultures were purified, sub cultured and preserved under $4^{\circ} \mathrm{C}$.

Gunathilake et al., (2013) isolated cellulose degrading bacteria and fungi from soil, compost and leaf litter. Sahni and Phutela (2013) isolated several cellulose degrading fungi from soil, compost, digested slums and plant debris using paddy straw agar medium containing chloramphenicol. Mahanta et al., (2014) also isolated and evaluated native cellulose degrading microorganisms for efficient bioconversion of weed biomass and rice straw. Padaria et al., (2014) isolated a total of 144 microbes from soils of Darjeeling hills of India, among which only few isolates were found to be cellulose degraders under in vitro conditions using CMC agar plate method.

The morphotypes of bacteria, actinomycetes and fungi were selected to get maximum number of diverse groups. Among all the samples maximum number of bacteria were isolated from long term straw incorporation fields, actinomycetes from compost experiment and fungi from rotten wood logs in forest. Overall maximum number of morphotypes was obtained from long term straw incorporation followed by rotten wood logs (Table 1 and Figure 3).

\section{Qualitative assay for screening of cellulolytic microorganisms}

All the bacterial, actinomycetes and fungal cultures were screened for cellulolytic activity using qualitative assay on CMCase agar medium. The bacterial and actinomycetes cultures were spot inoculated on the centre of 
petriplates, while for fungal cultures a $6 \mathrm{~mm}$ disk on centre of solid medium was placed followed by incubation for 7 days at $30^{\circ} \mathrm{C}$. Among all the 653 cultures screened, 44 bacterial cultures, 2 actinomycetes cultures and two fungal culture exhibited formation of zone using congo red dye. The diameter of hydrolysis zone varied from $2 \mathrm{~mm}$ to $32 \mathrm{~mm}$. Largest zones were obtained from the culture CDM35 followed by CDM5, CDM10, CDM2 and CDM23 while, it was minimum for CDM25, CDM29, CDM33 and CDM34 (Table 2). Cellulases can convert cellulose into monomeric or dimeric structures hence carboxymethyl cellulose (CMC) was used as a carbon source, it is a soluble form of cellulose (Angsana 2009; Sissons et al., 1987; Sazci and Erenler 1986). Kasana et al., (2008) has also used four dyes to determine cellulase activity in different cultures.

The reason for zone formation in the plates treated with dyes is that it binds with the polysaccharide and forms a visible complex. Cellulase produced by celluloytic microorganisms in the plate breaks down the polysaccharide as a result of which area surrounded by colony were exhausted with polysaccharides and replaced with smaller monosaccharides and disaccharides. These mono and disaccharide dyes cannot be bind efficiently to the dye hence results in the formation of a visible clear zone. Padaria et al., (2014) used congo red dye and $\mathrm{NaCl}$ solution for screening cellulose degrading bacteria. The zone of clearance ranged from $8.16 \mathrm{~mm}$ to $26.83 \mathrm{~mm}$. Sharma et al., (2013) isolated 43 potential cellulolytic and xylanolytic bacteria from compost. Gomashe et al., (2013) also screened bacterial and fungal cultures for cellulase activity on CMC agar plates but with $1 \%$ congo red dye. Ponnambalam et al., (2011) performed Congo red clearing zone assay for qualitative display of cellulase activity. Gaur and Tiwari (2015) isolated fifty bacterial cultures among which only twenty nine bacterial isolates exhibited good cellulase activity. These cultures were reassessed for cellulolytic potential by loading their culture broth in the wells on CMC agar plates and staining them with Congo-red and $\mathrm{NaOH}$ solution.

Among all the 48 cultures highest number of cellulolytic cultures were obtained from forest samples i.e. $35.4 \%$ followed by $29.2 \%$ from incorporation of crop residues followed by $25 \%$ from compost samples, $6.3 \%$ from field soil and $4.2 \%$ from cow dung (Figure 4). On the basis of zone of hydrolysis obtained on CMC agar media with congo red dye, the cultures were divided into four groups (zones $\leq 10 \mathrm{~mm}, \leq 20 \mathrm{~mm}, \leq 30 \mathrm{~mm}$ and $\leq 40 \mathrm{~mm}$ ). Among 48 cultures 21 cultures produced zones $\leq 10 \mathrm{~mm}$ and among these $14.6 \%$ cultures were from incorporation samples, $10.4 \%$ cultures were from forest, $8.3 \%$ from compost, $6.3 \%$ from field soil and $4.2 \%$ from cow dung. Twenty one cultures produced zones $\leq 20 \mathrm{~mm}$, among which $20.8 \%$ cultures were from forest followed by $10.4 \%$ from incorporation and $12.5 \%$ from compost however, no culture was obtained from cow dung and field soil. Four cultures exhibited formation of $\leq 30 \mathrm{~mm}$ zones among which $4.2 \%$ cultures were from incorporation and 4.2 $\%$ cultures were from compost. Highest zones of $\leq 40 \mathrm{~mm}$ were obtained from $4.2 \%$ cultures from forest ecosystem (Figure 5). So overall highest number of efficient cultures was obtained from forest followed by incorporation and compost samples. LopezMondejar et al., (2016) performed the screening and identification of bacteria showing potential cellulolytic activity from litter and organic soil of a temperate oak forest. Stursova et al., (2012) concluded that the cellulose represents a preferred substrate for bacteria, whereas fungi are able to utilize a wider range of litter constituents. These findings are in accordance to our study as among all the potential cultures maximum cellulolytic cultures were bacteria (Fig. 2). 
Table.1 Sampling sites, source and number of microorganisms isolated from different sites

\begin{tabular}{|c|c|c|c|c|c|c|c|}
\hline \multirow[t]{2}{*}{ S.No. } & \multirow[t]{2}{*}{ Place } & \multirow{2}{*}{$\begin{array}{l}\text { Sample } \\
\text { number }\end{array}$} & \multirow[t]{2}{*}{ Source } & \multicolumn{3}{|c|}{ Number of morphotypes isolated } & \multirow[t]{2}{*}{ Total } \\
\hline & & & & Bacteria & Actinomycetes & Fungus & \\
\hline \multirow[t]{5}{*}{1} & \multirow[t]{5}{*}{ PAU } & S1 & Paddy incorporation & 25 & 2 & 2 & 29 \\
\hline & & $\mathbf{S 2}$ & $\begin{array}{l}\text { Poplar cropping } \\
\text { system }\end{array}$ & 12 & 1 & 2 & 15 \\
\hline & & S3 & Crop retention & 13 & 3 & 0 & 16 \\
\hline & & S4 & Compost & 20 & 4 & 1 & 25 \\
\hline & & S5 & Termite mounds & 10 & 2 & 3 & 15 \\
\hline \multirow[t]{4}{*}{2} & \multirow[t]{4}{*}{ Faridkot } & S6 & Cow dung & 15 & 1 & 1 & 17 \\
\hline & & S7 & Cowdung+straw & 15 & 1 & 5 & 21 \\
\hline & & S8 & Decomposed straw & 35 & 2 & 6 & 43 \\
\hline & & S9 & Open compost trial & 15 & 1 & 0 & 16 \\
\hline \multirow[t]{6}{*}{3} & \multirow[t]{6}{*}{ Palampur } & S10 & Argemone compost & 25 & 1 & 4 & 30 \\
\hline & & S11 & Rice-wheat & 26 & 0 & 6 & 32 \\
\hline & & S12 & Forest soil & 30 & 2 & 8 & 40 \\
\hline & & S13 & Him compost & 2 & 0 & 0 & 2 \\
\hline & & S14 & Steria compost & 3 & 0 & 0 & 3 \\
\hline & & S15 & Lantana compost & 4 & 0 & 0 & 4 \\
\hline \multirow[t]{3}{*}{4} & \multirow[t]{3}{*}{ Harike } & S16 & $\begin{array}{l}\text { Rotten wood logs in } \\
\text { forest }\end{array}$ & 33 & 3 & 12 & 48 \\
\hline & & S17 & Undisturbed forest & 27 & 0 & 7 & 34 \\
\hline & & S18 & $\begin{array}{l}\text { Forest soil with } \\
\text { residues }\end{array}$ & 20 & 0 & 6 & 26 \\
\hline \multirow[t]{2}{*}{5} & \multirow[t]{2}{*}{ Moga } & S19 & Paddy incorporated & 20 & 1 & 3 & 24 \\
\hline & & $\mathbf{S 2 0}$ & Rotten wood & 24 & 2 & 4 & 30 \\
\hline \multirow[t]{4}{*}{6} & \multirow[t]{4}{*}{ Bathinda } & S21 & $\begin{array}{l}\text { Rotten wood log } \\
\text { forest }\end{array}$ & 36 & 3 & 5 & 44 \\
\hline & & $\mathbf{S 2 2}$ & Wheat straw & 24 & 0 & 6 & 30 \\
\hline & & $\mathbf{S 2 3}$ & Forest soil & 16 & 0 & 3 & 19 \\
\hline & & S24 & Paddy straw & 2 & 0 & 4 & 6 \\
\hline \multirow[t]{3}{*}{7} & \multirow[t]{3}{*}{ Hisar } & S25 & Wheat field 1 & 8 & 1 & 3 & 12 \\
\hline & & S26 & Wheat field 2 & 12 & 0 & 1 & 13 \\
\hline & & S27 & $\begin{array}{l}\text { Long term straw } \\
\text { incorporation field }\end{array}$ & 44 & 1 & 4 & 49 \\
\hline \multirow[t]{2}{*}{8} & Ladhowal & S28 & $\begin{array}{l}\text { Rice-Wheat } \\
\text { incorporation }\end{array}$ & 4 & 2 & 4 & 10 \\
\hline & & & Total & 520 & 33 & 100 & 653 \\
\hline
\end{tabular}


Table.2 In vitro screening of microbial cultures for cellulolytic activity

\begin{tabular}{|c|c|c|c|c|}
\hline S. No. & Microbial cultures & Isolates & Source of isolation & Zone of hydrolysis (mm) \\
\hline 1 & CDM 1 & Bacteria & Field soil & 5.0 \\
\hline 2 & CDM 2 & Bacteria & Compost & 27.0 \\
\hline 3 & CDM 3 & Bacteria & Cow dung & 5.0 \\
\hline 4 & CDM 4 & Bacteria & Incorporation & 13.0 \\
\hline 5 & CDM 5 & Bacteria & Forest & 31.0 \\
\hline 6 & CDM 6 & Bacteria & Field soil & 10.0 \\
\hline 7 & CDM 7 & Bacteria & Incorporation & 13.0 \\
\hline 8 & CDM 8 & Bacteria & Incorporation & 26.0 \\
\hline 9 & CDM 9 & Bacteria & Compost & 13.0 \\
\hline 10 & CDM 10 & Bacteria & Compost & 29.0 \\
\hline 11 & CDM 11 & Bacteria & Compost & 13.0 \\
\hline 12 & CDM 12 & Bacteria & Incorporation & 7.0 \\
\hline 13 & CDM 13 & Bacteria & Forest & 9.0 \\
\hline 14 & CDM 14 & Bacteria & Field soil & 5.0 \\
\hline 15 & CDM 15 & Bacteria & Forest & 12.0 \\
\hline 16 & CDM 16 & Bacteria & Cow dung & 7.0 \\
\hline 17 & CDM 17 & Bacteria & Incorporation & 6.0 \\
\hline 18 & CDM 18 & Bacteria & Incorporation & 12.0 \\
\hline 19 & CDM 19 & Bacteria & Incorporation & 12.0 \\
\hline 20 & CDM 20 & Bacteria & Forest & 13.0 \\
\hline 21 & CDM 21 & Bacteria & Incorporation & 11.0 \\
\hline 22 & CDM 22 & Bacteria & Forest & 16.0 \\
\hline 23 & CDM 23 & Bacteria & Incorporation & 27.0 \\
\hline 24 & CDM 24 & Bacteria & Forest & 11.0 \\
\hline 25 & CDM 25 & Bacteria & Incorporation & 3.0 \\
\hline 26 & CDM 26 & Actinomycetes & Forest & 16.0 \\
\hline 27 & CDM 27 & Bacteria & Compost & 10.0 \\
\hline 28 & CDM 28 & Bacteria & Incorporation & 6.0 \\
\hline 29 & CDM 29 & Bacteria & Forest & 3.0 \\
\hline 30 & CDM 30 & Bacteria & Forest & 6.0 \\
\hline 31 & CDM 31 & Bacteria & Forest & 5.0 \\
\hline 32 & CDM 32 & Bacteria & Forest & 7.0 \\
\hline 33 & CDM 33 & Bacteria & Compost & 2.0 \\
\hline 34 & CDM 34 & Bacteria & Incorporation & 5.0 \\
\hline 35 & CDM 35 & Bacteria & Forest & 32.0 \\
\hline 36 & CDM 36 & Bacteria & Forest & 15.0 \\
\hline 37 & CDM 37 & Bacteria & Forest & 12.0 \\
\hline 38 & CDM 38 & Bacteria & Forest & 4.0 \\
\hline 39 & CDM 39 & Bacteria & Compost & 5.0 \\
\hline 40 & CDM 40 & Bacteria & Incorporation & 5.0 \\
\hline 41 & CDM 41 & Bacteria & Forest & 13.0 \\
\hline 42 & CDM 42 & Actinomycetes & Compost & 18.0 \\
\hline 43 & CDM 43 & Bacteria & Compost & 5.0 \\
\hline 44 & CDM 44 & Bacteria & Incorporation & 9.0 \\
\hline 45 & CDM 45 & Fungi & Compost & 7.0 \\
\hline 46 & CDM 46 & Fungi & Compost & 13.0 \\
\hline 47 & CDM 47 & Bacteria & Compost & 15.0 \\
\hline 48 & CDM 48 & Bacteria & Forest & 11.0 \\
\hline
\end{tabular}

Incubation period $=7$ days

Incubation temperature $=30^{\circ} \mathrm{C}$ 
Fig.2 Number of morphotypes of bacteria, actinomycetes, fungi and total morphotypes obtained from each sample

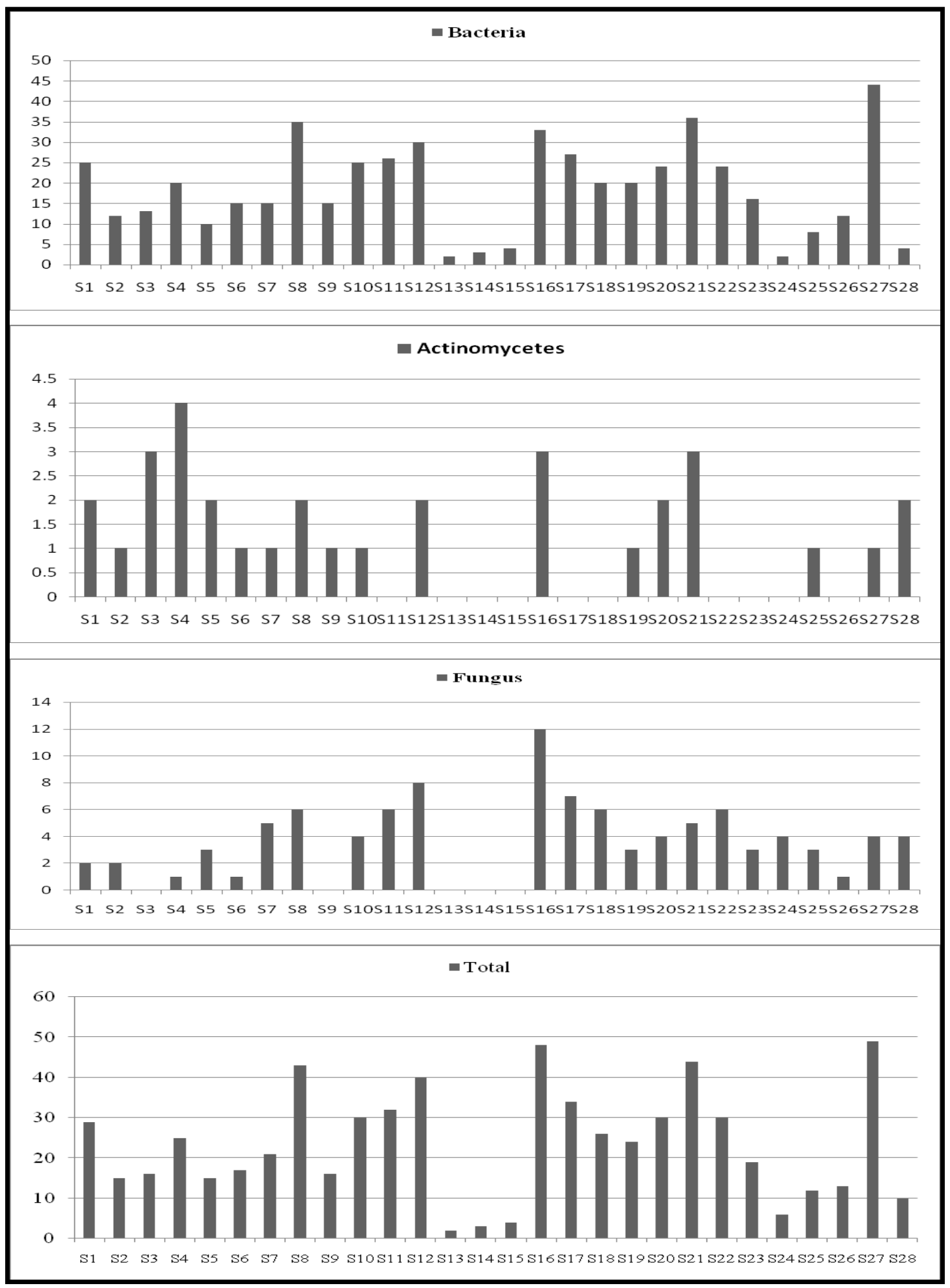


Fig.1 Isolation of (a) actinomycetes, (b) bacterial and (c) fungal cultures on their respective media

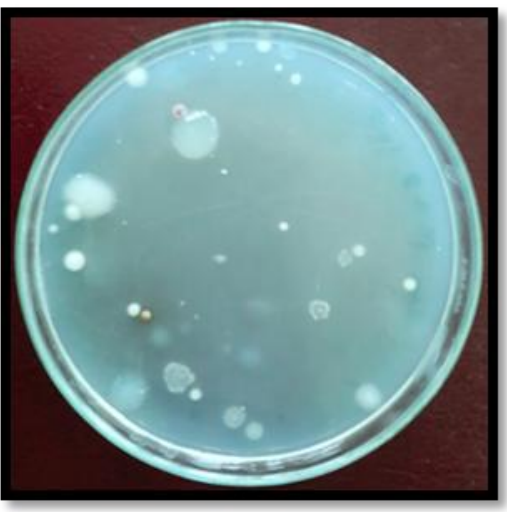

(a)

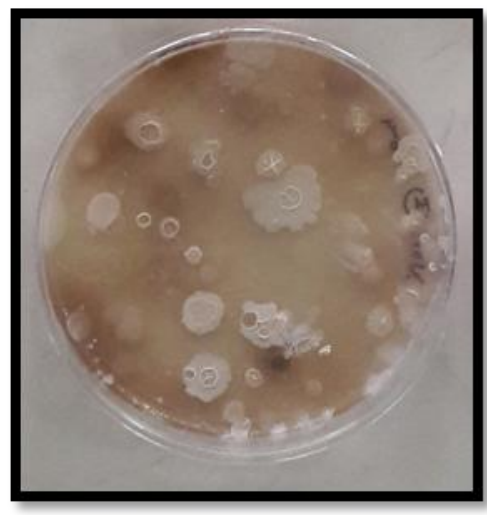

(b)

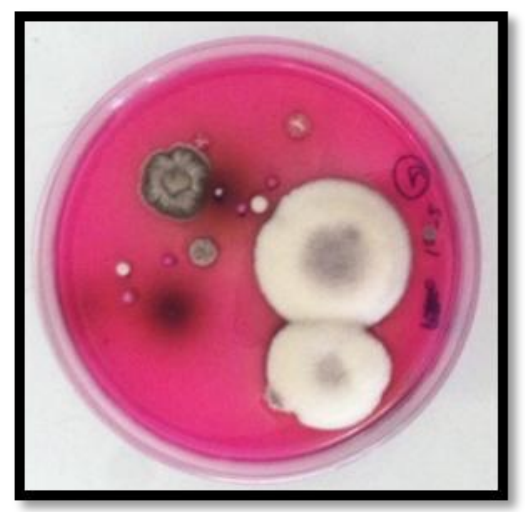

(c)

Fig.3 Zone of clearance of a) actinomycete culture b) bacterial culture and c) fungal culture on agar plate after staining with Congo red
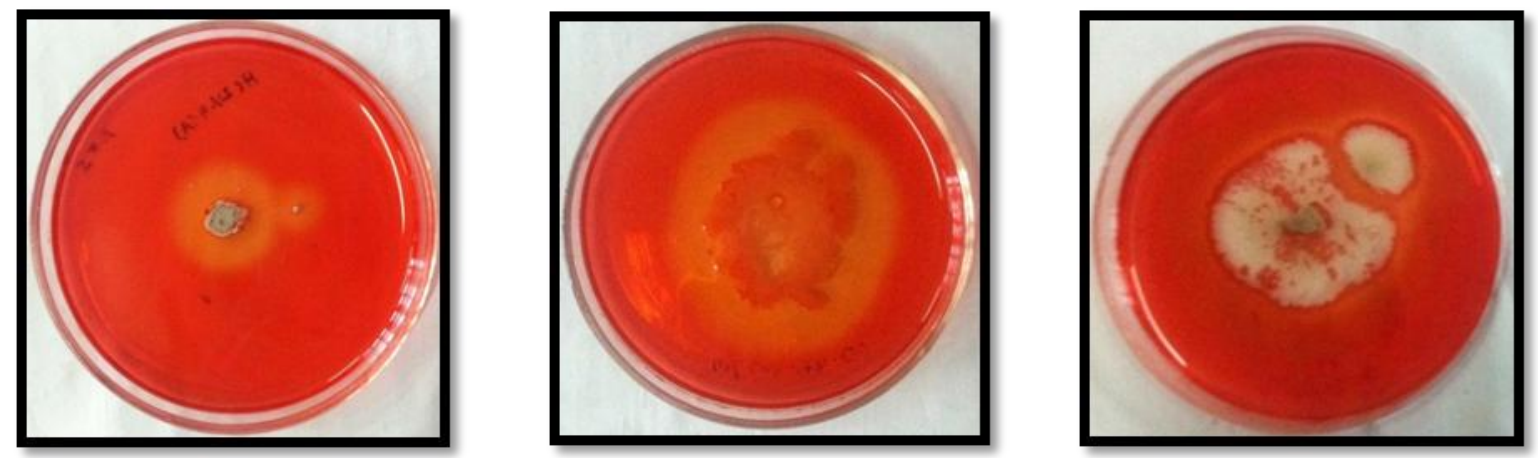

Fig.4 Percentage of efficient cellulolytic cultures obtained from different sources

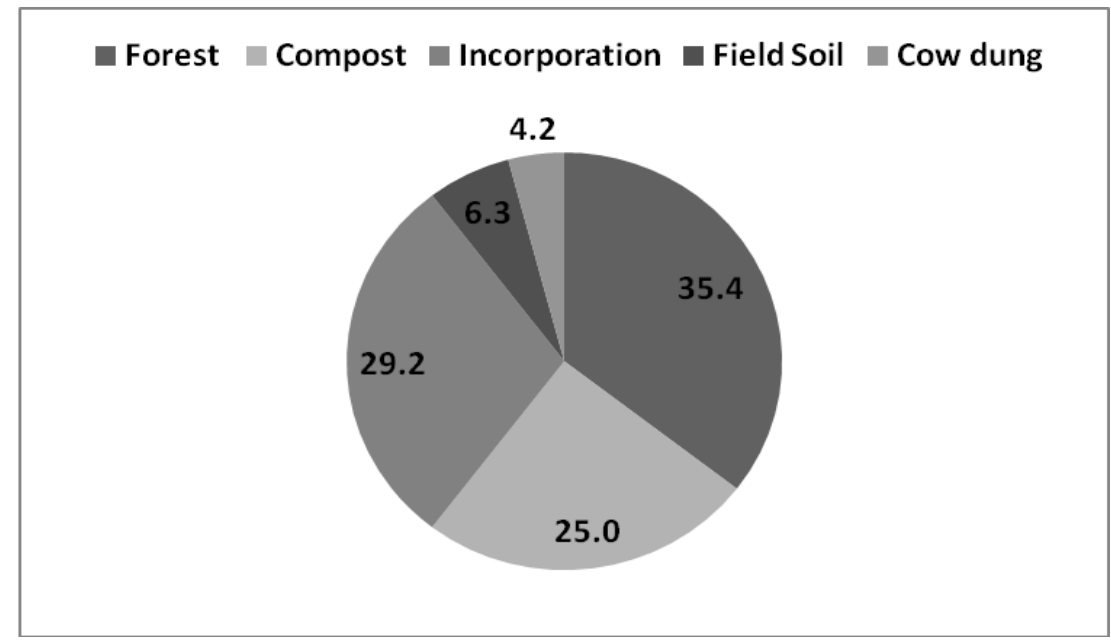


Fig.5 Per cent efficiency of microbial cultures on the basis of zone of hydrolysis

Forest $₫$ Incorporation $\square$ Compost $\square$ Cowdung $\square$ Field soil

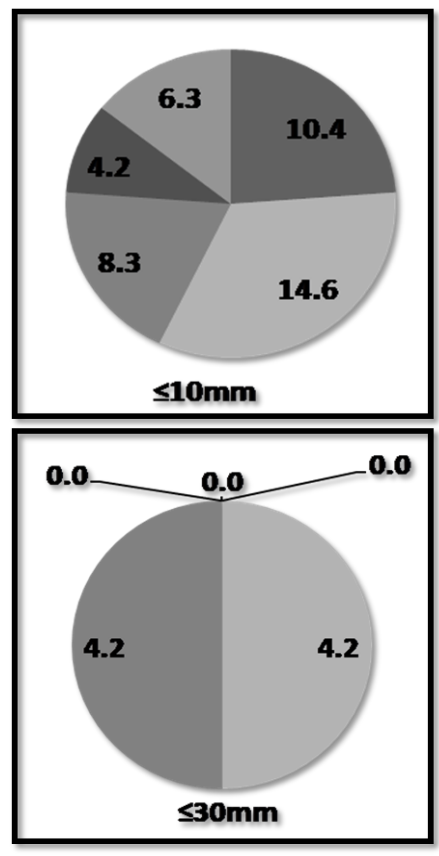

Rawway et al., (2018) also carried out a study in which he found maximum number of cellulolytic cultures i.e. $40.83 \%$ were obtained from garden soil followed by $26.67 \%$ from gut of ruminant, $15.83 \%$ from compost, $10.83 \%$ from agricultural soil and $5.83 \%$ from River Nile sediment.

The possible reason for obtaining highest number of cultures from forest could be that forest represents an ecosystem where the plant litter, both above and below ground is decomposed by the microbial succession so a large number of microorganisms are involved in this decomposition process. In case of incorporation of crop residues, the plant material is incorporated in the field and then specific groups of microbes acts on the residue components resulting in its decomposition. In case of composting, different types of microbes appear at different stages of composting which includes mesophilic and thermophilic organisms. These systems represents an environment

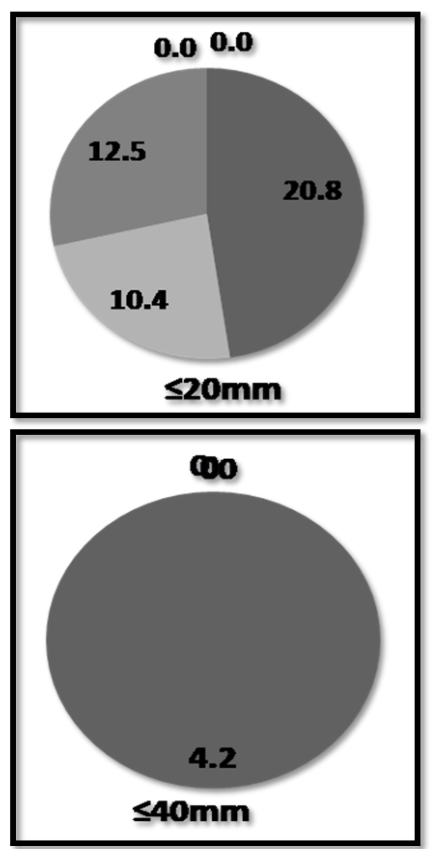

where we can get maximum diversity and abundance of lignocellulolytic microbes. However, direct isolations of microorganisms from cow dung or field soil comparatively represents less abundance of cellulolytic microbes.

So from the observations made in this study we can conclude that forests represents a rich source of microbial biodiversity. Further understanding of these systems with respect to microbial biodiversity will be helpful to study decomposition processes, synergism between different microorganisms and the biochemical basis of degradation of residues in forest.

\section{References}

Angsana, R., Warinthorn, S. Annop, N. and Pawinee, C. (2009) Combination effect of $\mathrm{pH}$ and acetate on enzymatic cellulose hydrolysis. Journal of Environmental Science 21, 965-970. 
Gaur, R. and Tiwari, S. (2015) Isolation, production, purification and characterization of an organic-solventthermostable alkalophilic cellulase from Bacillus vallismortis RG-07. BMC Biotechnology 19, 15-19.

Gomashe, A.V., Gulhane, P.A. and Bezalwar, P.M. (2013) Isolation and Screening of Cellulose Degrading Microbes from Nagpur Region Soil. International Journal of Life Sciences 1(4), 291293.

Gunathilake, K.M.D., Ratnayake R.R., Kulasooriya S.A. and Karunaratne D.N. (2013) Evaluation of cellulose degrading efficiency of some fungi and bacteria and their biofilms. Journal of National Science Foundation Sri Lanka 41(2), 155-163.

Kasana, R.C., Salwan, R., Dhar, H., Dutt, S. and Gulati, A. (2008) A rapid and easy method for the detection of microbial cellulases on agar plates using gram's iodine. Current Microbiology 57(5), 503-7.

Larney, F.C. and Angers, D.A. (2012) The role of organic amendments in soil reclamation: A review. Canadian Journal of Soil Science 92(1), 19-38.

López-Mondéjar, R., Zühlke, D., Becher, D., Riedel, K. and Baldrian, P. (2016) Cellulose and hemicelluloses decomposition by forest soil bacteria proceeds by the action of structurally variable enzymatic systems. Scientific Reports 6: 25279.

Mahanta K., Jha D.K., Rajkhowa D.J. and Kumar, M. (2014) Isolation and evaluation of native cellulose degrading microorganisms for efficient bioconversion of weed biomass and rice straw. Journal of Environmental Biology 35,721-725.

Minamiyama, H., Shimizu, M., Kunoh, H., Furumai, T., Igarashi, Y., Onaka, H. and Yoshida, R. (2003)Multiplication of isolate R-5 of Streptomyces galbus on rhododendron leaves and its production of cell wall-degrading enzymes. Journal of General Plant Pathology 69, 65-70.

Munten, W. (2005). Beneficial Soil microorganisms. Soil and Plant Laboratory Inc., Bellevue, WA, pp. 12.

Padaria, J. C., Sarkar, K., Lone, S. A. and Srivastava, S. (2014) Molecular characterization of cellulosedegrading Bacillus pumilus from the soil of tea garden, Darjeeling hills, India. Journal of Environmental Biology, Vol. 35, 555-561.

Parton, W. J., W. L. Silver, and I. C. Burke (2007), Global-scale similarities in nitrogen release patterns during longterm decomposition, Science, 315, 361-164.

Ponnambalam, A.S., Deepthi, R.S. and Ghosh, A.R. (2011) Qualitative display and measurement of enzyme activity of isolated cellulolytic bacteria. Biotechnology Bioinformatics and Bioengineering, 1, 33-37.

Rawway, M., Ali, S.G. and Badawy, A.S. (2018) Isolation and Identification of Cellulose Degrading Bacteria from Different Sources at Assiut Governorate (Upper Egypt) Journal of Ecology of Health and Environment, 6(1), 15-24.

Sazci, A. and Erenler, K., 1986. Detection of cellulolytic fungi by using Congo red as an indicator: a comparative study with the dinitrosalicylic acid reagent method. Journal of Applied Bacteriology, 61, 559562.

Sahni, N. and Phutela, U. (2013) Isolation and preliminary screening of paddy straw degrading thermophilic fungi. Indian Journal of Applied Research, 3(10), 13 
Sissons, C.H., Sharrock, K.R., Daniel, R.M. and Morgan, H.W. (1987) Isolation of Cellulolytic Anaerobic Extreme Thermophiles from New Zealand Thermal Sites. Applied and Environmental Microbiology 53(4), 832838.

Stursová, M., Zifčáková, L., Leigh, M.B., Burgess, R. and Baldrian, P. (2012)
Cellulose utilization in forest litter and soil: identification of bacterial and fungal decomposers. FEMS Microbiol Ecol. 80(3), 735-46.

$\mathrm{Yu}, \quad$ J. (2007) Microbial production of bioplastics from renewable resources. Renewable Resources 585-610.

\section{How to cite this article:}

Gurpreet Singh, Neemisha and Sandeep Sharma. 2018. Influence of Sampling Sites on the Occurrence and Distribution of Cellulose Degrading Microbial Communities. Int.J.Curr.Microbiol.App.Sci. 7(08): 1880-1890. doi: https://doi.org/10.20546/ijcmas.2018.708.216 